Biol. Neonate 1978;33:I-IV

\title{
Contents, Vol. 33, 1978
}

\section{No. 1-2}

Harel, S.; Shapiia, Y.; Hartzler, J.; Teng, E.L.;

Quiligan, E., and Van Der Meulen, J.P.: Neuromotor Development in Relation to Birth

Weight in Rabbits 1

Fowler, S.A.; Williams, M.E., and Gray, T.K.:

Calcium and 25-Hydroxyvitamin D3 Binding

Proteins in Human Placenta 8

Ballowitz, L.; Hanefeld, F.; Jerofke, R.; Keller, P.;

Korn, J., and Schweitzer, U.: Sephadex-Gel

Filtration (SGF) in Infant and Adult Gunn

Rats 13

Coppa, G.V.; Gabrielli, O.; Maiorana, A.; Sani, S.;

Benincasa, A.; Belsito, M., and Montali, U.:

Undersulfated Urinary Giycosaminoglycans in

Pre term Newborn s

18

Boda, D. and Eck, E.: In vitro Effects of Inosine-

Pyruvate-Phosphate on Ps0 Values and DPG

Contents of Fresh and Stored Blood from

Healthy Neonates, Symptom-Free Premature

Infants and Premature Infants with Respira

tory Distress Syndrome 25

Croskerry, P.G.; Smith, G.K.; Hall, S., and

Shepard, B.J.: Fetal and Placental Growth in the Rat following Differential Reduction of

Litter Size 31

Habib, Z.: Maternal Plasma $\alpha$-Feto-Protein in Pregnancies Terminating in Spontaneous Abor tion 39

Davis, B.M.; Miller, R.K.; Brent, R.L., and Koszalka, T.R.: Materno-Fetal Transport of Creatine in the Rat 43

Maxwell, G.M.; Dahlenburg, G.W., and Rencis, V:

Urinary Content of 3',5'-Adenosine Mono-

phosphate (cAMP) and Creatinine in Full-Term

and Premature Infants 55

Lipp, K.; Meulen, N. van der; Wenske, G., and

Linneweh, F.: Orotic Acid: Its Influence on

Nuclear RNA and Microsomal Protein Syn 
thesis in Brain Cells of Undernourished Rat

Pups 62

Ogata, E.S. and HoUiday, M.A.: The Effects of

Glucose and Alanine Infusion on Urea Produc

tion and Gluconeogenesis in the Starved New

born Guinea Pig 66

Corbier, P. and Roffi, J.: Increased Adrenocortical

Activity in the Newborn Rat 72

Rothberg, R.M.; Rieger, Ch.H.L.; Hill, J.H.;

Danielson, J., and Matadial, L.: Cord and

Maternal Serum Meperidine Concentrations

and Clinical Status of the Infant 80

Saunders, R.A.; Milner, A.D., and Hopkin, I.E.:

Longitudinal Studies of Infants with the

Wilson-Mikity Syndrome. Clinical, Radiologi

cal and Mechanical Correlations 90

Raul, F.; Simon, P.M.; Kedinger, M.; Grenier, J.F.,

and Haffen, K.: Sucrase and Lactase Synthesis

in Suckling Rat Intestine in Response to

Substrate Administration $\quad 100$

Meban, C.: Influence of $\mathrm{pH}$ and Temperature on

Behaviour of Surfactant from Human Neo

natal Lungs 106

No. 3-4

Holloway, W.R., jr.; Dollinger, M.J., and Denen-

berg, V.H.: Body and Organ Growth in the

Newborn Rat 113

Carmichael, R.D.; Gordon, A.S., and LoBue, J.:

The Effects of Maternal Phlebotomy and

Orally-Administered Erythropoietin (Ep) on

Erythropoiesis in the Suckling Rat 119

Jirsová, V. and Janovsky, M.: Hyperbilirubinemia

Connected with Parenteral Administration of

Higher Amounts of Fluids in Premature In

fants 132

Walker, A.M.; Cannata, J.; Dowling, M.H.; Ritchie, B., and Maloney, J.E.: Sympathetic and

Para-sympathetic Control of Heart Rate in Un-anaesthetized Fetal and Newborn Lambs ... 135

Hoerter, J.A. and Opie, L.H.: Perinatal Changes in Glycolytic Function in Response to Hypoxia

in the Incubated or Perfused Rat Heart .... 144

IV

Contents

Paynton, B.V.; Schmidt, R.R., and Cotler, J.M.:

Effects of the Teratogenic Folic Acid Antag

onist, 9-Methyl Pteroylglutamic Acid on

Uronic Acid Levels in Fetal Rat Limbs 
Parer, J.T.: Oxygen Consumption of the Fetal

Sheep in utero

Csaba, G.; Darvas, Z.; László, V.; Juvancz, I.;

Vargha, P.; Bodrogi, L., and Fehér, T.: Long-

Lasting Effect of Single Ecdysone Injections

in Newborn Rats

Liebman, W.M. and Samloff, I.M.: Fetal Pepsin-

ogens in Human Amniotic Fluid

Djaldetti, M.; Goldman; J.A., and Fishman, P.:

Ultrastructure of the Cells in the Peripheral

Blood of Human Embryos at Early Gestational

Stages

Bührdel, P.; Wiügerodt, H.; Keller, E., and Theile,

H.: Postnatal Development of Rats Born Pre-

term and Postterm. I. Body Weight

Meloni, T.; Costa, S.; Corti, R., and Cutillo, S.:

Salicylamide Glucuronide Formation in New

born Babies with G-6-PD Deficiency

Hommes, F.A. and Everts, R.S.: Particulate and

Free Hexokinase in Fetal Rat Liver

Legrèle, C; Felix, J.M.; Droulle-Bertignon, C;

Potron, G., and Jacquot, R.: Evolution of

Fibrinogen Levels in Rat Fetal and Maternal

Blood during Gestation

Obenshain, S.S.; Isaccsohn, M.; King, K., and Schwartz, R.: Sequential Intravenous Glucose

Tolerance: Responses of Newborn and Adult

Freundl, K. and Van Wynsberghe, D.M.: The

Effects of Thyroid Hormones on Myelination

in the Developing Rat Brain

No. 5-6

Berman, W., jr.; Goodlin, R.C.; Heymann, M.A., and Rudolph, A.M.: Effects of Pharmacologic

Agents on Umbilical Blood Flow in Fetal

Lambs in utero

Delitala, G.; Meloni, T.; Masala, A., and Corti, R.:

Thyrotropin, Prolactin and Growth Hormone

Response to Synthetic Thyrotropin-Releasing

Hormone in Newborn Infants

Bührdel, P.; Keller, E.; Willgerodt, H., and Theile, H.: The Postnatal Development of Rats Born

Preterm and Postterm. II. Liver, Brain, Heart

and Kidneys 240

Ip, H.M.-H.: Intrauterine Growth in Hong Kong

162 Chinese 253

Cutts, J.H.; Krause, W.J., and Leeson, C.R.:

167 General Observations on the Growth and

Development of the Young Pouch Opossum, 
Didelphis virginiana 264

Roord, J.J. and Ramaekers, L.H.J.: Quantifica-

170 tion of Intrauterine Malnutrition 273

Rubaltelli, F.F.; Stramentinoli, G.; Chiozza, M.L.;

174 Saia, O.S., and Cantarutti, F.: Postnatal

Changes in Blood S-Adenosylmethionine Con

centration. Some Observations in Hyaline

Membrane Disease 278

177 Das, S.K.; Nair, R.C.; Patthey, H.L., and Mgbodile,

M.U.K.: The Effects of Aflatoxin B1 on Rat

Fetal Lung Lipids 283

184 Gautier, C. and Vaülant, R.: Effects of Administration of Hydrocortisone, ActinomycinD

and Puromycin on Carbamoylphosphate Synthe-

189 thase-I and Ornithine Carbamoyltransferase

Activities in Fetal Rat Liver 289

193 Metzger, P. and Brachet, E.: The Rabbit during

the Last Third of Gestation. Data Concerning

the Whole Fetus, Its Diaphragm and Brown

Adipose Tissue 297

201 Mallet, E.; Basuyau, J.-P.; Brunelle, P.; Devaux, A.-M., and Fassard, C: Neonatal

Parathyroid Secretion and Renal Receptor Maturation in

207 Premature Infants 304

Stygles, V.G.; Smith, W.L.; Reinke, D.A., and Hook, J.B.: Prostaglandin-Forming Cyclooxy217 genase in Renal Medulla of Spontaneously

Hypertensive Rats during Development .... 309 Milner, A.D.; Saunders, R.A., and Hopkin, I.E.:

Relationship of Intra-Oesophageal Pressure to Mouth Pressure during the Measurement of

Thoracic Gas Volume in the Newborn 314

Rubaltelli, F.F.; Enzi, G.; De Biasi, F.; Bondio, M., and Rondinelli, M.: Effect of Lipid Load-

225 ing on Fetal Uptake of Free Fatty Acids,

Glycerol, and/3-Hydroxybutyrate 320

236 Varia 112,224

Author Index 327

Subject Index 329 